\title{
PENGEMBANGAN PERANGKAT PEMBELAJARAN FISIKA BERBASIS PENDIDIKAN KARAKTER DENGAN MODEL PROBLEM BASED INSTRUCTION
}

\author{
Rahma Diani \\ Program Studi Pendidikan Fisika IAIN Raden Intan Lampung \\ E-mail: emailrahmaaa@gmail.com
}

Diterima: 9 Agustus 2015 Disetujui: 11 Oktober 2015. Dipublikasikan: Oktober 2015

\begin{abstract}
The unavailable of physics material learning based by the character education which conform with students' characteristic caused the students' competency and activity in study process was low. This research aims to develop physics material learning (syllabus, lesson plan, module, worksheet, and assessment) based by the character education with validity, practical, and effective problem based instruction model for the temperature and heat subject. This research was the development research by using $4 D$ models. The phases are define, design, and develop. The researcher did the analysis of curriculum, analysis of concepts, and analysis of students at define phase. On design phase, the researcher designed the physics material learning. Develop phase consist of validation phase, practicality, and effectivity. After designed, the physics material learning was validated by 5 validator. At practicality phase, physics material learning tested by the students of XB MAN 1 Sungai Penuh on even semester 2012/2013. At this activity, student and teacher will be ask for their comments about the practicality of physics material learning. Effectivity of physics material learning investigated at the same time with practicality phase. At this activity, student and teacher will be ask for their comments about the effectivity of physics material learning. Effectivity also seen from the improving of student's competency and student's activity in study process. The result showed that physics material learning based character education with model of problem based instruction are very valid, very practical and very effective.
\end{abstract}

\begin{abstract}
Abstrak: Ketidaktersediaan materi pembelajaran fisika dengan pendidikan karakter yang sesuai dengan karakteristik siswa karena kompetensi dan kegiatan siswa dalam proses belajar termasuk rendah. Penelitian ini bertujuan untuk mengembangkan bahan ajar fisika (silabus, rencana pembelajaran, modul, lembar kerja, dan penilaian) berdasar pada pendidikan karakter dengan validitas, prktik, dan masalah efektif berdasarkan model instruksi materi suhu dan kalor. Penelitian ini merupakan penelitian pengembangan menggunakan model 4D. Tahapan tahapannya ialah; menjelaskan, desain, dan mengembangkan. Peneliti menganalisa kurikulum, menganalisa konsep, dan menganalisa siswa pada tahap tertentu. Pada tahap desain, peneliti mendesain bahan ajar fisika. Mengembangkan tahapan yang terdiri dari tahap validasi, praktikalitas, dan efektifitas. Setelah di desain, bahan ajar fisika divalidasi oleh 5 validator. Pada tahapan praktikalitas, bahan ajar fisika di uji oleh siswa kelas XB MAN 1 Sungai Penuh pada semester genap 2012/2013. Pada kegiatan ini, siswa dan guru akan ditanyakan komentarnya tentang prktikalitas pada bahan ajar fisika. Efektifitas pada bahan ajar fisika diteliti pada saat yang sama dengan tahap praktikalitas. Efektifitas juga dilihat dari meningkatnya kompetensi dan kegiatan siswa pada proses pembelajaran. Hasil menunjukkan bahwa bahan ajar fisika berdasarkan pendidikan karakter dengan instruksi Problem Based Model sangat valid, sangat praktikal dan sangat efektif.
\end{abstract}

Kata Kunci: model problem based instruction, pendidikan karakter, perangkat pembelajaran fisika

\section{PENDAHULUAN}

Gunawan (2012:28) menyebutkan bahwa, pendidikan karakter merupakan upaya-upaya yang dirancang dan dilaksanakan secara sistematis untuk menanamkan nilai-nilai perilaku peserta didik yang berhubungan dengan Tuhan Yang Maha Esa, diri sendiri, sesama manusia, lingkungan, dan kebangsaan yang terwujud dalam pikiran, sikap, 
perasaan, perkataan, dan perbuatan berdasarkan norma-norma agama, hukum, tata karma, budaya, dan adat istiadat. Berdasarkan penjelasan ini, pendidikan karakter dapat diyakini sebagai aspek penting dalam pendidikan terutama dalam upaya peningkatan Sumber Daya Manusia (SDM).

Nilai-nilai pendidikan karakter dapat diintegrasikan ke dalam proses pembelajaran, termasuk dalam pembelajaran fisika. Fisika menjelaskan berbagai gejala fisis fenomena yang terjadi di alam, baik secara teori maupun perhitungan. Hal ini mengindikasikan bahwa terdapat ruang-ruang dalam mata pelajaran fisika yang dapat dijadikan sebagai sarana dalam mengembangkan nilai-nilai pendidikan karakter pada diri siswa, asalkan pembelajaran fisika di dilaksanakan dengan sebagaimana mestinya.

Hasil wawancara dengan salah satu guru fisika kelas $\mathrm{X}$ MAN 1 Sungai Penuh, menunjukkan bahwa pembelajaran fisika yang dilaksanakan di madrasah belum sesuai dengan apa yang diharapkan. Setelah diamati, ternyata perangkat pembelajaran fisika yang digunakan guru dalam pembelajaran belum mendukung tercapainya tujuan tersebut, misalnya silabus. Silabus yang digunakan guru belum berbasis pendidikan karakter. Silabus tersebut juga masih belum spesifik dan belum sesuai dengan karakteristik siswa, hal ini terlihat dari indikator pencapaian kompetensi dan kegiatan pembelajaran yang terdapat pada silabus. Selain silabus, Rencana Pelaksanaan Pembelajaran (RPP) yang digunakan guru masih belum lengkap komponenkomponennya. Untuk metode pembelajaran yang digunakan dalam pembelajaran memang sudah ada variasi. Dalam pembelajaran selain menggunakan metode ceramah, guru juga menggunakan metode diskusi, namun tetap saja masih belum bisa membelajarkan siswa secara keseluruhan. Akibatnya, hanya sebagian kecil siswa yaitu yang berkemampuan tinggilah yang aktif dalam kegiatan pembelajaran di kelas sedangkan yang lainnya tidak. Pada langkah-langkah pembelajaran di RPP juga belum tercantum nilai-nilai pendidikan karakter yang ingin dikembangkan.

Perangkat pembelajaran lain yang diamati adalah bahan ajar fisika yang digunakan, bahan ajar tersebut ternyata jugatidak sesuai dengan karakteristik siswa. Selain itu, bahan ajar ini juga belum bisa menumbuhkan atau mengoptimalkan karakter pada diri siswa. Dalam pembelajaran guru menggunakan beberapa buku paket dari penerbit, sedangkan siswa hanya diwajibkan untuk memiliki bahan ajar berupasatu buah LKS. Pada LKS yang digunakan siswa, ditemukan materi suhu dan kalor masih kurang lengkap. Sementara siswa terbilang malas untuk mencari literaturliteratur lain yang berhubungan dengan suhu dan kalor, padahal semakin banyak literatur yang digunakan siswa tentunya akan semakin baik, karena siswa dapat menggali lebih dalam mengenai materi suhu dan kalor ini. Siswa tidak mungkin memiliki semua buku yang beredar dipasaran karena jumlahnya terlalu banyak dan harganya yang relatif mahal. Selain LKS sebagai bahan ajar, siswa tidak memiliki LKS yang menuntun siswa dalam melaksanakan eksperimen. Hal ini menyebabkan aktivitas belajar siswa kurang maksimal. Sementara itu, dari segi lembar penilaian yang digunakan guru, terlihat bahwa indikator kompetensi siswa tidak sesuai dengan lembar penilaian yang digunakan guru, sehingga penilaian yang dilakukan belum maksimal. Penilaian hendaknya dilaksanakan dalam setiap kegiatan pembelajaran sehingga dapat mengukur kompetensi kognitif, afektif, dan psikomotor siswa dengan baik. Dari 
pengamatan terhadap perangkat pembelajaran yang digunakan ini, dapat disimpulkan bahwa perangkat pembelajaran yang digunakan dalam pembelajaran belum bisa mendukung terciptanya aktivitas, kompetensi, dan karakter siswa yang lebih baik.

Wawancara juga dilakukan dengan beberapa siswa madrasah. Dari wawancara ini diperoleh informasi bahwa, sebagian besar siswa beranggapan materi-materi pembelajaran fisika itu susah. Hal ini menyebabkan siswa malas untuk belajar. Selain itu, sebagian besar siswa juga malas mengerjakan latihan atau pekerjaan rumah (PR) yang diberikan guru dan kalaupun dikerjakan, itu bukanlah hasil kerja siswa sendiri, akan tetapi diperoleh dengan cara mencontek hasil pekerjaan siswa lainnya. Hal-hal seperti ini jelas menunjukkan karakter yang tidak baik berkembang pada diri siswa.

Upaya yang dapat dilakukan untuk mengatasi permasalah di atas adalah dengan mengembangkan suatu perangkat pembelajaran fisika berbasis pendidikan karakter yang sesuai dengan karakteristik siswa dan dapat mengarahkan serta merangsang aktivitas belajar siswa. Perangkat pembelajaran fisika berbasis pendidikan karakter yang akan dikembangkan adalah silabus, RPP, LKS, bahan ajar, dan penilaian. Untuk bahan ajar, akan dikembangkan sebuah modul pembelajaran. Dipilihnya modul pembelajaran, adalah untuk memudahkan siswa dalam memahami materi pembelajaran suhu dan kalor baik dengan guru (di kelas) maupun tanpa guru (belajar mandiri). Dengan modul, siswa dapat belajar di mana saja dan kapan saja tanpa dibatasi oleh waktu seperti pada pembelajaran di kelas.

Nilai-nilai pendidikan karakter tidak dikembangkan secara serentak dalam suatu pembelajaran tetapi disesuaikan dengan substansi materi pembelajaran suhu dan kalor dan langkah-langkah model problem based instruction. Nilai-nilai pendidikan karakter yang dikembangkan pada penelitian ini adalah religius, rasa ingin tahu, jujur, kerja keras, disiplin, berpikir kritis, dan kerjasama. Dengan adanya pembatasan ini, diharapkan karakter yang muncul pada diri siswa benar-benar dapat teramati dengan baik.

Model pembelajaran yang digunakan dalam mengembangkan perangkat pembelajaran ini adalah model problem based instruction. Tan (2003) dalam Rusman (2011:229) yang mengemukakan bahwa "Pembelajaran berbasis masalah merupakan inovasi dalam pembelajaran karena dalam PBM kemampuan berpikir siswa betul-betul dioptimalisasikan melalui proses kerja kelompok atau tim yang sistematis, sehingga siswa dapat memberdayakan, mengasah, menguji, dan mengembangkan kemampuan berpikirnya secara berkesinambungan". Dengan demikian, modelproblem based instruction adalah model pembelajaran yang berlandaskan paham konstruktivistik yang mengakomodasi keterlibatan siswa dalam belajar dan pemecahan masalah autententik. Pemilihan model problem based instructiondidasari karena model ini dapat merangsang serta meningkatkan aktivitas berpikir siswa, karena pada model pembelajaran ini siswa dilibatkan dalam suatu pemecahan masalah yang disajikan oleh guru. Pembelajaran fisika di MAN 1 Sungai Penuh pada materi suhu dan kalor pada dasarnya tidak berhasil dalam membelajarkan siswa secara keseluruhan, karena perangkat pembelajaran yang digunakan tidak dapat merangsang setiap siswa untuk berpikir, sehingga materi yang disampaikan guru tidak bermakna dan hanya didengar siswa untuk kemudian terlupakan. Untuk itulah melalui penerapan modelproblem based 
instruction kedalam perangkat pembelajaran yang digunakan, dapat menciptakan pembelajaran yang memungkinkan siswa untuk dapat belajar secara aktif dan menyenangkan.

Riyanto (2010:286) mengemukakan mengenai peranan guru dalam pelaksanaan model problem based instruction, "Dalam pembelajaran ini, guru berperan mengajukan permasalahan nyata, memberikan dorongan, memotivasi dan menyediakan bahan ajar dan fasilitas yang diperlukan peserta didik untuk memecahkan masalah. Selain itu, guru memberikan dukungan dalam upaya meningkatkan temuan dan perkembangan intelektual peserta didik". Artinya, dalam pelaksanaan pembelajaran problem based instruction, guru dituntut untuk mengembangkan suatu perangkat pembelajaran yang sesuai sehingga mendukung optimalnya pelaksanaan model ini. Dengan demikian, penelitian ini bertujuan untuk mengembangkan perangkat pembelajaran fisika berbasis pendidikan karakter dengan model problem based instruction yang valid, praktis, dan efektif. Pengembangan perangkat pembelajaran fisika berbasis Pendidikan karakter dapat di kembangkan (Akhlis \& Dewi, 2014) (Taufiq, Dewi, \& Widiyatmoko, 2014) (Widiyatmoko, 2013) (Izzati, Hindarto, \& Pamelasari, 2013)

Adapun langkah-langkah model problem based instructionterdapat pada Tabel 1.

Tabel 1. Langkah-langkah model problem based instruction

\begin{tabular}{clrl}
\hline No & \multicolumn{1}{c}{ Indikator } & \multicolumn{3}{c}{ Tingkah Laku Guru } \\
\hline 1 & $\begin{array}{l}\text { Orientasi siswa pada } \\
\text { masalah }\end{array}$ & $\begin{array}{l}\text { Menjelaskan tujuan pembelajaran, menjelaskan logistic yang } \\
\text { diperlukan, dan memotivasi siswa terlibat pada aktivitas } \\
\text { pemecahan masalah. }\end{array}$ \\
\hline 2 & $\begin{array}{l}\text { Mengorganisasi } \\
\text { untuk belajar }\end{array}$ & siswa & $\begin{array}{l}\text { Membantu siswa mendefinisikan dan mengorganisasikan } \\
\text { tugas belajar yang berhubungan dengan masalah tersebut. }\end{array}$ \\
\hline 3 & $\begin{array}{l}\text { Membimbing pengalaman } \\
\text { individual/kelompok }\end{array}$ & $\begin{array}{l}\text { Mendorong siswa untuk mengumpulkan informasi yang } \\
\text { sesuai, melaksanakan eksperimen untuk mendapatkan } \\
\text { penjelasan dan pemecahan masalah }\end{array}$ \\
\hline 4 & $\begin{array}{l}\text { Mengembangkan dan } \\
\text { menyajikan hasil karya }\end{array}$ & $\begin{array}{l}\text { Membantu siswa dalam merencanakan dan menyiapkan karya } \\
\text { yang sesuai seperti laporan, dan membantu mereka untuk } \\
\text { berbagi tugas dengan temannya }\end{array}$ \\
\hline 5 & $\begin{array}{l}\text { Menganalisis } \\
\text { mengevaluasi dan } \\
\text { pemecahan masalah }\end{array}$ & $\begin{array}{l}\text { Membantu siswa untuk melakukan refleksi atau evaluasi } \\
\text { terhadap penyelidikan mereka dan proses yang mereka } \\
\text { gunakan }\end{array}$ \\
\hline
\end{tabular}

(2011:243)

Sumber:

Rusman

Kelima langkah inilah yang akan digunakan dalam mengembangkan perangkat pembelajaran yang terdiri dari silabus, RPP, modul, LKS, dan penilaian.

\section{METODE PENELITIAN}

Penelitian ini merupakan penelitian pengembangan (research and the development). Dalam penelitian ini akan dikembangkan perangkat pembelajaran fisika berbasis pendidikan karakter dengan menggunakan model problem based instruction pada materi suhu dan kalor yang valid, praktis, dan efektif, serta sesuai kondisi dan kebutuhan nyata. Perangkat pembelajaran yang dikembangkan adalah silabus, RPP, modul, LKS dan penilaian.

Model pengembangan perangkat pembelajaran yang digunakan adalah model 4-D yang terdiri dari empat tahap, yaitu pendefinisian (define), perancangan (design), pengembangan (develop), dan penyebaran (desseminate). 
Pengembangan perangkat ini dilakukan sampai tahap develop saja.

\section{HASIL DAN PEMBAHASAN}

\section{Tahap Pendefinisian (define)}

Pada tahap pendefinisian, dilakukan analisis terhadap kurikulum, siswa, dan konsep. Hasil analisis mengidikasikan bahwa, dalam pembelajaran suhu dan kalor di kelas $X_{B}$ dibutuhkan perangkat pembelajaran (silabus, RPP, modul, LKS, dan penilaian) yang benar-benar dapat membelajarkan siswa secara keseluruhan. Perangkat tersebut haruslah dapat mengoptimalkan aktivitas berpikir siswa, salah satunya melalui pemecahan masalah. Hal ini penting dilakukan agar materi suhu dan kalor yang disajikan benar-benar dapat menjadi fokus siswa ketika pembelajaran dilaksanakan. Selain itu, banyak konsep suhu dan kalor yang bersifat abstrak sehingga sangat membutuhkan aktivitas berfikir siswa balam memahaminya. Untuk mendukung optimalnya aktivitas berpikir siswa dapat digunakan matode lain, yaitu metode eksperimen dan metode diskusi.

Selain itu, perangkat pembelajaran yang digunakan juga harus berbasis pendidikan karakter agar siswa tidak hanya memahami materi pembelajaran suhu dan kalor, tetapi juga memahami, menyadari, dan pada akhirnya menginternalisasikan nilai-nilai pendidikan karakter di dalam diri masing-masing siswa. Keberadaan pendidikan karakter ini juga dapat membuat pembelajaran yang dilakukan siswa menjadi lebih bermakna, sehingga melekat diingatan siswa. Untuk memenuhi semua kebutuhan ini, maka dikembangkanlah perangkat pembelajaran fisika berbasis pendidikan karakter dengan model problem based instruction untuk materi suhu dan kalor.

\section{Tahap Perancangan (design)}

a. Rancangan Silabus

Komponen-komponen silabus dirancang sesuai dengan permendiknas Nomor 41 tahun 2007. Kop silabus berisikan identitas mata pelajaran yang meliputi: satuan pendidikan, kelas, semester, program/program keahlian, mata pelajaran atau tema pelajaran, dan jumlah pertemuan. Selanjutnya, matriks silabus terdiri dari kompetensi dasar, materi pembelajaran, nilai-nilai pendidikan karakter, kegiatan pembelajaran, indikatorpencapaian kompetensi, penilaian, alokasi waktu, dan sumber belajar. Rancangan matrik silabus dapat dilihat pada Gambar 1.

\begin{tabular}{|c|c|c|c|c|c|c|c|}
\hline $\begin{array}{l}\text { Kompetensi } \\
\text { Dasar }\end{array}$ & $\begin{array}{c}\text { Materi } \\
\text { Pembelajaran }\end{array}$ & $\begin{array}{l}\text { Nilai-nilai } \\
\text { Pendidikan } \\
\text { Karakter }\end{array}$ & Kegiatan Pembelajaran & $\begin{array}{c}\text { Indikator Pencapaian } \\
\text { Kompetensi }\end{array}$ & Penilaian & $\begin{array}{c}\text { Alokasi } \\
\text { waktu }\end{array}$ & $\begin{array}{l}\text { Sumber } \\
\text { Belajar }\end{array}$ \\
\hline $\begin{array}{l}4.1 \\
\text { Menganalisis } \\
\text { pengaruh } \\
\text { kalor } \\
\text { terhadap } \\
\text { suatuzat }\end{array}$ & $\begin{array}{l}\text { Pengaruh kalor } \\
\text { terhadap suhu } \\
\text { zat }\end{array}$ & $\begin{array}{l}\text { 1. Jujur } \\
\text { 2. Kerja } \\
\text { keras } \\
\text { 3. Disiplin } \\
\text { 4. Rasa ingin } \\
\text { tahu } \\
\text { 5. Religius } \\
\text { 6. Kerjasama }\end{array}$ & $\begin{array}{l}\text { 1. Orientasi siswa pada masalah: } \\
\text { Guru memintasiswa duduk } \\
\text { berkelompok sesuai kelompok } \\
\text { yang telah ditetapkan sebelumnya } \\
\text { dan dilanjutkan dengan } \\
\text { menggiring siswamerumuskan } \\
\text { masalah yangberhubungan } \\
\text { dengan pengaruh kalor terhadap } \\
\text { suhu zat, menjelaskan tujuan } \\
\text { pembelajaran, menjelaskan } \\
\text { logistikyang diperlukan, dan } \\
\text { memotivasisiswa terlibat pada } \\
\text { aktivitas pemecahan masalah (rasc } \\
\text { ingin tahu, religius, dan kerjasama) } \\
\text { 2. Mengorganisasikan siswa untuk } \\
\text { belajar: Guru menjelaskan apa }\end{array}$ & $\begin{array}{l}\text { A. Kognitif } \\
\text { 1. Proses } \\
\text { Melakukan } \\
\text { pembelajaran dengan } \\
\text { menggunakan } \\
\text { langkah-langkah } \\
\text { model problem based } \\
\text { instruction.Langkah- } \\
\text { langkah tersebut } \\
\text { adalah: } \\
\text { a. Orientasi siswa } \\
\text { pada masalah } \\
\text { b. Mengorganisasi } \\
\text { siswa untuk } \\
\text { belajar } \\
\text { c. Membimbing }\end{array}$ & Tes tertulis & $3 \times 45^{\prime}$ & $\begin{array}{l}-\mathrm{W}, \mathrm{A} 1, \mathrm{~A} 2 \text {, } \\
\text { A4, dan A9 } \\
\text { - Lingkungan }\end{array}$ \\
\hline
\end{tabular}

Gambar 1. Rancangan matriks silabus

Kompetensi dasar untuk materi suhu dan kalor, terdiri atas: menganalisis pengaruh kalor terhadap suatu benda, menganalisis cara perpindahan kalor, dan menerapkan asas Black dalam pemecahan masalah. Materi pembelajaran terdiri atas: pengaruh kalor terhadap suhu benda, pemuaian, 
perubahan wujud zat, perpindahan kalor, dan asas Black. Nilai pendidikan karakter terdiri atas: religius, jujur, kerja keras, disiplin, rasa ingin tahu, berpikir kritis, dan kerjasama. Kegiatan pembelajaran dirancang sesuai dengan langkah model problem based instruction, yaitu: orientasi siswa pada masalah, mengorganisasi siswa untuk belajar, membimbing pengalaman individual/kelompok, mengembangkan dan menyajikan hasil karya, serta menganalisis dan mengevaluasi proses pemecahan masalah. Indikator pencapaian kompetensi dirumuskan dari kompetensi dasar untuk kompetensi kognitif, afektif (karakter), dan psikomotor. Penilaian dirancang untuk kompetensi kognitif berupa tes tertulis, kompetensi afektif berupa lembar penilaian perilaku berkarakter, dan psikomotor berupa lembar penilaian kinerja. Alokasi waktu untuk setiap pertemuan adalah $3 \times 45$ menit. Sumber belajar yang digunakan terdiri dari modul, LKS, lingkungan dan beberapa buku anjuran. Dari hasil perancangan terlihat bahwa silabus yang dirancang telah lengkap komponen-komponennya dan telah sesuai dengan kondisi (kebutuhan) kegiatan pembelajaran fisika pada materi suhu dan kalor.

b. Rancangan RPP

Rancangan RPP disesuaikan dengan permendiknas Nomor 41 tahun 2007.
RPP disusun untuk lima kali pertemuan. Komponen-komponen RPP yang rancang terdiri dari identitas mata pelajaran, standar kompetensi, kompetensi dasar, indikator pencapaian kompetensi, tujuan pembelajaran, materi ajar, alokasi waktu, metode pembelajaran, kegiatan pembelajaran, penilaian hasil belajar, dan sumber belajar.

Identitas mata pelajaran, meliputi: satuan pendidikan, kelas, semester, program, mata pelajaran atau tema pelajaran, dan jumlah pertemuan. Standar kompetensi, kompetensi dasar, indikator pencapaian kompetensi, alokasi waktu, penilaian hasil belajar, dan sumber belajar sama seperti yang tercantum pada silabus. Tujuan pembelajaran dirumuskan berdasarkan indikator pencapaian kompetensi untuk kompetensi kognitif, afektif, dan psikomotor. Materi ajar terdiri atas fakta, konsep, prinsip, dan prosedur. Metode pembelajaran yang digunakan antara lain: ceramah, diskusi, tanya jawab, eksperimen, dan penugasan. Selanjutnya, untuk kegiatan pembelajaran disesuaikan dengan langkah-langkah model problem based instruction dengan mencantumkan nilai-nilai pendidikan karakter yang akan dikembangkan pada siswa. Rancangan kegiatan pembelajaran yang dirancang pada RPP dapat dilihat pada Gambar 2. 


\begin{tabular}{|c|c|c|c|c|}
\hline No & Aktivitas Guru & Aktivitas Siswa & $\begin{array}{c}\text { Nilai } \\
\text { Karakter }\end{array}$ & $\begin{array}{l}\text { Alokasi } \\
\text { Waktu }\end{array}$ \\
\hline 1. & $\begin{array}{l}\text { Mendorong siswa untuk } \\
\text { melakukan do'a } \\
\text { sebelum belajar dengan } \\
\text { tertib }\end{array}$ & $\begin{array}{l}\text { Melaksanakan do'a } \\
\text { sebelum belajar } \\
\text { dengan tertib }\end{array}$ & $\begin{array}{l}\text { Religius dan } \\
\text { disiplin }\end{array}$ & \multirow[t]{5}{*}{$\begin{array}{c}15 \\
\text { menit }\end{array}$} \\
\hline 2. & $\begin{array}{l}\text { Mengecek dan } \\
\text { memastikan kehadiran } \\
\text { siswa }\end{array}$ & $\begin{array}{l}\text { Tertib dan jujur } \\
\text { dalam memberikan } \\
\text { informasi tentang } \\
\text { kehadiran siswa }\end{array}$ & $\begin{array}{l}\text { Disiplin dan } \\
\text { jujur }\end{array}$ & \\
\hline 3. & $\begin{array}{l}\text { Memeriksa kesiapan } \\
\text { belajar siswa }\end{array}$ & $\begin{array}{l}\text { Tertib dan bersiap- } \\
\text { siap untuk } \\
\text { menerima pelajaran }\end{array}$ & $\begin{array}{l}\text { Disiplin dan } \\
\text { jujur }\end{array}$ & \\
\hline 4. & $\begin{array}{l}\text { Mengajukan pertanyaan } \\
\text { apersepsi dan } \\
\text { mendorong siswa untuk } \\
\text { menjawab. Pertanyaan } \\
\text { tersebut adalah: } \\
\text { Apakah yang dimaksud } \\
\text { dengan kalor? }\end{array}$ & $\begin{array}{l}\text { Berusaha menjawab } \\
\text { pertanyaan guru } \\
\text { dengan tertib }\end{array}$ & $\begin{array}{l}\text { Disiplin dan } \\
\text { kerja keras }\end{array}$ & \\
\hline 5. & $\begin{array}{l}\text { Orientasi siswa pada } \\
\text { masalah: }\end{array}$ & & & \\
\hline
\end{tabular}

Gambar 2. Rancangan kegiatan pembelajaran pada RPP

c. Rancangan Modul

Rancangan modul disesuaikan dengan kebutuhan standar kompetensi, kompetensi dasar, dan indikator pencapaian kompetensi yang telah dirumuskan. Modul terdiri atas beberapa bagian, yaitu: (1) petunjuk umum, yang memuat kompetensi dasar, pokok-pokok materi pembelajaran, indikator pencapaian, referensi atau buku-buku yang digunakan, strategi atau skenario pembelajaran, lembar kegiatan belajar, dan evaluasi; (2) materi pembelajaran, dan (3) lembar kerja, yang memuat soalsoal yang sesuai dengan materi pembelajaran yang telah diberikan.

Modul dirancang untuk lima kali pertemuan. Kegiatan belajar pada modul disesuaikan dengan langkah model problem based instruction. Kegiatan belajar diawali dengan menggiring siswa merumuskan masalah sampai pada akhirnya menemukan pemecahan dari rumusan masalah tersebut. Modul didesain semenarik mungkin, baik dari segi warna maupun layoutnya agar dapat menarik perhatian siswa. Uraian materi disajikan dengan bahasa yang sederhana tetapi tidak mengurangi maksud dari materi. Rancangan modul juga memuat fitur yang berhubungan dengan nilai-nilai pendidikan karakter yang akan dikembangkan pada diri siswa agar siswa mengenali, menyadari, dan menginternalisasi nilai tersebut ke dalam diri masing-masing siswa seperti pada Gambar 3. Selain itu, modul juga memuat fitur 'ingat" yang dapat mempermudah siswa dalam mengingat konsep-konsep penting yang berhubungan dengan materi pembelajaran. 



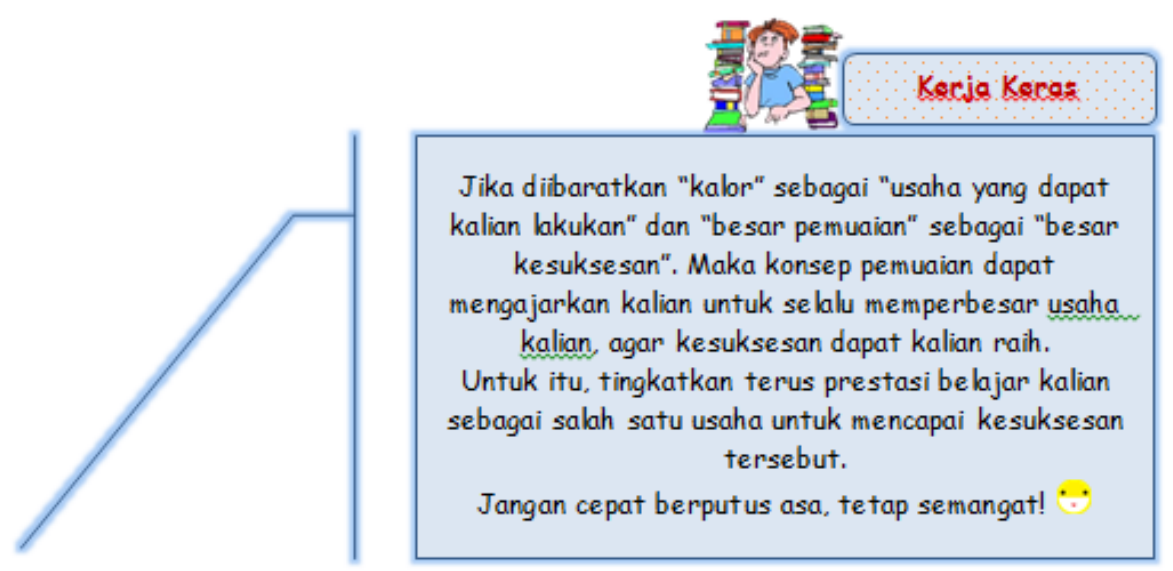

Gambar 3. Rancangan fitur nilai pendidikan karakter pada modul

\section{d. Rancangan LKS}

Rancangan LKS disesuaikan dengan kebutuhan modul yang dikembangkan. LKS juga dirancang untuk lima kali pertemuan. Kelima LKS yang dirancang adalah LKS eksperimen yang menuntun siswa dalam melaksanakan eksperimen. Komponen LKS terdiri dari: judul eksperimen, tujuan, teori singkat tentang materi, alat dan bahan, prosedur eksperimen, data pengamatan, serta pertanyaan dan kesimpulan.

Judul eksperimen disesuaikan dengan judul submateri suhu dan kalor yang diajarkan. Judul ini kemudian dirinci menjadi subjudul beserta tujuannya yang mengarah siswa langsung pada pemecahan rumusan masalah yang telah dirumuskan pada modul. Teori singkat tentang materi berisi konsep- konsep tentang materi suhu dan kalor yang berhubungan dengan eksperimen yang akan dilaksanakan. Alat dan bahan informasi mengenai alat-alat dan bahanbahan apa saja yang dituhkan untuk melaksanakan eksperimen. Selanjutnya, prosedur eksperimen berisikan langkahlangkah yang dilakukan dalam melaksanakan eksperimen seperti pada Gambar 4. Prosedur eksperimen dirangkaikan langsung dengan data pengamatan yang ingin diperoleh. Pertanyaan-pertanyaan di dalam LKS bertujuan untuk memandu siswa dalam menemukan konsep-konsep mengenai suhu dan kalor. Pada kesimpulan siswa diminta untuk menyimpulkan hasil eksperimen yang telah dilakukan. Sekaligus menghubungkan dengan pemecahan rumusan masalah yang telah dirumuskan oleh siswa pada modul. 
Langkah-langkah eksperimen:

1. Tuang 0,2 kg air ke dalam gelas kimia

2. Letakkan gelas kimia yang berisi air di atas kaki tiga dengan menggunakan alas kawat kasa

3. Masukkan termometer ke dalam air

4. Panaskan air dengan menggunakan pembakar spiritus selama 10 menit. Amati suhu air untuk setiap selang waktu 1 menit dan catat hasil pengamatan kalian pada Tabel 1

Tabel 1. Data Pengamatan

\begin{tabular}{|c|c|}
\hline Waktu (menit) & Suhu $\left({ }^{\circ} \mathrm{C}\right.$ ) \\
\hline 0 & \\
\hline 1 & \\
\hline 2 & \\
\hline 3 & \\
\hline 4 & \\
\hline 5 & \\
\hline
\end{tabular}

Gambar 4.Rancangan prosedur eksperimen pada LKS

e. Rancangan Penilaian

Rancangan penilaian disesuaikan dengan indikator-indikator pencapaian kompetensi yang telah dirumuskan.

\section{Soal:}

1. Jelaskan pengaruh kalor terhadap ukuran zat! (skor: 20)

2. Jelaskan hal-hal yang mempengaruhi pemuaian! (skor: 10)

3. Jelaskan tentang pemuaian pada zat padat, cair, dan gas beserta contohrya dalam kehidupan sehari-hari! (skor: 20)

4. Apakah yang dimaksud dengan anomali air? Jelaskan! (skor: 10)

5. Sebuah bola berongga terbuat dari perunggu $\left(a=18 \times 10^{-6}\left({ }^{\circ} \mathrm{C}\right)^{-1}\right)$ pada suhu $0^{\circ} \mathrm{C}$, jari-jarinya $=1 \mathrm{~m}$. Jika bola tersebut dipanaskan sampai $80^{\circ} \mathrm{C}$, hitunglah

(a)

Penilaian Perilaku Berkarakter

\section{Petunjuk:}

Berilah skor 1, 2, 3, atau 4 pada tabel penilaian perilaku berkarakter siswa yang telah disediakan di bawah ini. 1, 2, 3, atau 4 memiliki makna sebagai berikut:

\begin{tabular}{|c|l|l|}
\hline Skor & \multicolumn{1}{|c|}{ Kategori } & \multicolumn{1}{c|}{ Keterangan } \\
\hline 1 & BT (Belum Terlihat) & Jika siswa belum memperlihatkan perilaku yangtertera dalam indikator \\
\hline 2 & MT (Mulai Terlihat) & Jika siswa mulai memperlihatkan perilaku yangtertera dalam indikator, tetapi belum konsisten \\
\hline 3 & MB (Mulai Berkembang) & Jika siswa mulai konsisten memperlihatkan perilaku yang tertera dalam indikator \\
\hline 4 & MK (Membudaya) & Jika siswa terus menerus/secara konsisten memperlihatkan perilaku yang tertera dalam indikator \\
\hline
\end{tabular}

Tabel Penilaian Perilaku Berkarakter Siswa

\begin{tabular}{|c|c|c|c|c|c|c|c|c|c|c|c|c|c|c|c|c|c|c|c|c|c|c|c|c|c|c|c|c|c|c|c|c|c|c|}
\hline \multirow{2}{*}{$\begin{array}{l}\mathrm{N} \\
\mathrm{o}\end{array}$} & \multirow{2}{*}{$\begin{array}{c}\text { Nilai } \\
\text { Karakter }\end{array}$} & \multirow{2}{*}{$\begin{array}{c}\text { Indikator Perilaku } \\
\text { Berkarakter }\end{array}$} & \multicolumn{32}{|c|}{ No Absen Siswa } \\
\hline & & & 1 & $z$ & 3 & 4 & 5 & 6 & 7 & 8 & 9 & 10 & 11 & 12 & 13 & 14 & 15 & \begin{tabular}{l|l|}
16 \\
\end{tabular} & 17 & 18 & 19 & 20 & 21 & 22 & 23 & 24 & 25 & 26 & 27 & 28 & 29 & 30 & 31 & 32 \\
\hline
\end{tabular}

(b) 


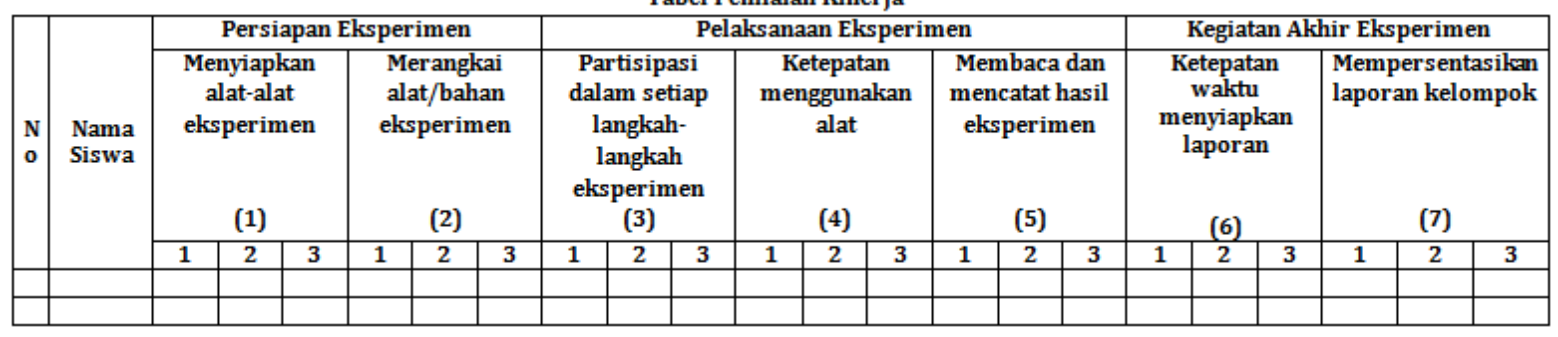

(c)

Gambar 5.(a)Rancangan penilaian kognitif, (b) Rancangan penilaian afektif, dan (c)Rancangan penilaian psikomotor

Pada penilaian kognitif, teknik yang digunakan adalah tes tertulis yang terdiri dari 3-6 soal essay yang harus dikerjakan siswa pada setiap pertemuan. Penilaian kognitif ini digunakan untuk mengukur kemampuan intelektual siswa.

Selanjutnya, pada penilaian afektif, teknik yang digunakan adalah penilaian perilaku berkarakter siswa untuk mengamati nilai-nilai pendidikan karakter yang ditunjukkan siswa selama proses pembelajaran. Pengamatan ini dilakukan oleh observer yang telah ditunjuk yaitu salah satu guru fisika di MAN 1 Sungai Penuh. Nilai-nilai pendidikan karakter yang diamati meliputi: religius, kerja keras, jujur, rasa ingin tahu, disiplin, perpikir kritis, dan kerjasama. Pada penilaian psikomotor, penilaian diambil dari kegiatan motorik yang berhubungan dengan tindakan yang memerlukan koordinasi antara saraf dan otot. Penilaian di pusatkan pada kegiatan siswa selama melakukan eksperimen. Teknik yang digunakan adalah penilaian kinerja siswa dalam melaksanakan eksperimen yang mencakup tahap persiapan, pelaksanaan, dan kegiatan akhir eksperimen. Ketiga rancangan penilaian ini dilengkapi dengan rubric penskoran untuk mengetahui berapa skor yang diperoleh siswa.

\section{Tahap Pengembangan (develop)}

a. Validitas Perangkat Pembelajaran

Perangkat pembelajaran masingmasing divalidasi sebanyak dua kali.
Meskipun pada validasi pertama telah dinyatakan bahwa perangkat pembelajaran yang dirancang sangat valid, kelima validator masih memberikan saran agar perangkat pembelajaran yang dirancang lebih baik lagi.

Nilai rata-rata persentase hasil validasi silabus yang pertama adalah $88,4 \%$ dan pada validasi kedua meningkat menjadi $91,9 \%$. Nilai rata-rata persentase hasil validasi RPP yang pertama adalah $89,9 \%$ dan pada validasi kedua meningkat menjadi $92,0 \%$. Nilai rata-rata persentase hasil validasi modul yang pertama adalah $88,8 \%$ dan pada validasi kedua meningkat menjadi 93,2\%. Nilai rata-rata persentase hasil validasi LKS yang pertama adalah $88,9 \%$ dan pada validasi kedua meningkat menjadi $92,0 \%$. Selanjutnya, nilai rata-rata persentase hasil validasi penilaian yang pertama adalah $88,2 \%$ dan pada validasi kedua meningkat menjadi 91,1\%.

Meningkatnya nilai rata-rata persentase validitas pada validasi kedua disebabkan oleh revisi yang dilakukan pada perangkat pembelajaran yang sesuai dengan saran dari validator. Persentase nilai ini menunjukkan bahwa perangkat pembelajaran fisika berbasis pendidikan karakter dengan model problem based instruction pada materi suhu dan kalor yang dirancang, sangat valid. Belum tercapainya nilai rata-rata persentase $100 \%$ untuk validasi ini diduga karena mungkin perangkat pembelajaran bisa 
lebih baik lagi, baik dari segi isi, konstruksi atau bahasa yang digunakan.

b. Praktikalitas Perangkat Pembelajaran Praktikalitas perangkat pembelajaran diperoleh dengan menggunakan angket respon guru terhadap praktikalitas perangkat pembelajaran. Persentase nilai rata-rata praktikalitas perangkat pembelajaran dari dua orang guru mata pelajaran fisika, yaitu $87,5 \%$ untuk silabus, $84,4 \%$ untuk RPP, $89,1 \%$ untuk modul, $89,6 \%$ untuk LKS, dan $85,0 \%$ untuk penilaian. Untuk RPP, praktikalitasnya juga dilihat dari lembar keterlaksanaan RPP dengan persentase nilai rata-rata keterlaksanaan RPP yang diperoleh adalah $91,5 \%$ untuk RPP pertemuan pertama, 96,0\% untuk RPP pertemuan kedua, 98,4\% untuk RPP pertemuan ketiga, $100 \%$ untuk RPP pertemuan keempat, dan $100 \%$ untuk RPP pertemuan kelima.

Praktikalitas perangkat pembelajaran juga diperoleh dengan menggunakan angket respon siswa terhadap praktikalitas perangkat pembelajaran. Persentase nilai rata-rata praktikalitas modul dari 32 siswa kelas $\mathrm{X}_{\mathrm{B}}$ MAN 1 Sungai Penuh yang diperoleh adalah 88,5\%, sedangkan untuk praktikalitas LKS adalah 90,8\%.

Persentase nilai ini menunjukkan bahwa perangkat pembelajaran fisika berbasis pendidikan karakter dengan model problem based instruction pada materi suhu dan kalor yang dirancang, sangat praktis. Hasil wawancara dengan kedua guru menyatakan bahwa belum tercapainya nilai $100 \%$ pada praktikalitas perangkat pembelajaran, dikarenakan perangkat pembelajaran ini masih baru bagi guru.Artinya, guru belum pernah menggunakan perangkat pembelajaran ini di dalam pembelajaran fisika.Persentase nilai rata-rata praktikalitas perangkat pembelajaran dari siswa juga terlihat belum mencapai $100 \%$.Hal ini dikarena ada beberapa siswa yang masih membutuhkan bimbingan dalam menggunakan modul dan LKS yang dirancang.

\section{c. Efektivitas Perangkat Pembelajaran}

Efektivitas perangkat pembelajaran diperoleh dengan menggunakan angket respon guru dan angket respon siswa terhadap efektivitas perangkat pembelajaran. Persentase nilai rata-rata efektivitas perangkat pembelajaran dari dua orang guru mata pelajaran fisika yang diperoleh adalah $90,7 \%$. Sementara itu, persentase nilai rata-rata efektivitas perangkat pembelajaran dari 32 siswa kelas $\mathrm{X}_{\mathrm{B}}$ MAN 1 Sungai Penuh yang diperoleh adalah $89,6 \%$. Kedua persentase nilai rata-rata efektivitas perangkat pembelajaran ini menunjukan bahwa perangkat pembelajaran fisika berbasis pendidikan karakter dengan menggunakan model problem based instruction yang dirancang, sangat efektif.

Persentase nilai rata-rata efektivitas perangkat pembelajaran dari guru terlihat belum mencapai $100 \%$. Hal ini dikarenakan guru masih khawatir dengan pelaksanaan perangkat pembelajaran ini karena belum pernah dilaksanakan sebelumnya. Selama ini guru merasa paling sulit meningkatkan kompetensi kognitif fisika siswa. Akibatnya, kedua guru sepakat memberikan penilaian yang kurang maksimal pada indikator penilaian praktikalitas modul yang pertama yaitu jika dibandingkan dengan perangkat pembelajaran yang sering digunakan, perangkat pembelajaran dengan model problem based instruction dapat lebih meningkatkan kompetensi kognitif siswa pada materi suhu dan kalor.

Hal yang berbeda justru terjadi pada persentase nilai rata-rata efektivitas perangkat pembelajaran dari siswa. Meskipun persentase nilai rata-rata 
efektivitas yang diperoleh juga belum mencapai $100 \%$, namun kebanyakan siswa malah memberikan penilaian yang kurang maksimal pada indikator penilaian efektivitas yang kedua, yaitu jika dibandingkan dengan perangkat pembelajaran yang sering digunakan guru, perangkat pembelajaran dengan model problem based instruction dapat lebih meningkatkan karakter saya menuju yang lebih positif (lebih baik). Dengan demikian siswa merasa perangkat pembelajaran dengan model problem based instruction dapat lebih meningkatkan kompetensi kognitif dari pada meningkatkan karakter. Hasil ini bukan berarti bahwa perangkat pembelajaran dengan model problem based instruction tidak dapat lebih meningkatkan karakter siswa menuju yang lebih positif (lebih baik), namun persentasenya saja yang lebih rendah dibandingkan yang lainnya. Hal ini diduga terjadi karena siswa belum terlalu percaya diri untuk menyatakan bahwa karakter siswa telah meningkat.

Efektifnya perangkat pembelajaran fisika berbasis pendidikan karakter dengan model problem based instruction kemudian dibuktikan dengan adanya peningkatan kompetensi dan aktivitas belajar siswa. Analisis kompetensi kognitif siswa, menunjukkan peningkatan pada setiap pertemuan dengan persentase ketuntasan sebesar $87,5 \%$.

Peningkatan kompetensi kognitif siswa ini disebabkan karena perangkat pembelajaran fisika berbasis pendidikan karakter dengan model problem based instructionsiswa diajak untuk menggunakan pemikirannya dari awal pembelajaran hingga pembelajaran selesai. Dengan adanya aktivitas berpikir siswa ini, siswa menjadi lebih terfokus pada pembelajaran, sehingga materi pembelajaran mudah dipahami siswa. Selain itu, pada perangkat pembelajaran fisika berbasis pendidikan karakter dengan model problem based instruction, siswa diajak untuk berdiskusi serta merumuskan masalah. Hal ini juga berpengaruh terhadap kompetensi kognitif siswa. Dengan meningkatnya aktivitas belajar siswa, maka hasil belajar siswapun turut meningkat (Diani, 2015). Dengan adanya otak siswa yang bekerja dengan lebih baik, maka materi pembelajaranpun mudah untuk dipahami siswa.

Hasil penilaian kompetensi afektif siswa yang diperoleh dari lembar penilaian perilaku berkarakter siswa juga menunjukkan adanya peningkatan. Peningkatan terjadi pada semua nilai pendidikan karakter yang dikembangkan, yaitu jujur, kerja keras, disiplin, rasa ingin tahu, religius, berpikir kritis, dan kerjasama.

Peningkatan perilaku berkarakter siswa terjadi karena siswa sudah mulai terbiasa mengikuti pembelajaran berbasis pendidikan karakter yang dilaksanakan. Alasan terpenting lainnya adalah karena perangkat pembelajaran fisika berbasis pendidikan karakter dengan model problem based instruction yang digunakan menuntut siswa untuk memiliki rasa ingin tahu, berpikir kritis dan kerja keras yang tinggi dalam merumuskan serta menemukan pemecahan rumusan masalah, disiplin yang tinggi dalam melaksanakan setiap kegiatan pembelajaran, kejujuran yang tinggi dalam menyampaikan pendapat dan hasil eksperimen yang diperoleh, dan kerjasama yang baik antar siswa dalam melakukan kegiatan pembelajaran, serta diimbangi pula dengan tingkat religius yang baik dari siswa. Dengan kata lain model problem based instruction secara tidak langsung mengandung nilai-nilai pendidikan karakter yang ingin dikembangkan. Hal yang tidak kalah penting berpengaruh terhadap peningkatan karakter siswa adalah adanya arahan dan motivasi yang tidak 
pernah hilang untuk diberikan kepada siswa selama pembelajaran berlangsung, sehingga siswa lebih terdorong untuk menunjukkan karakter yang lebih positif dari dirinya.

Hasil penilaian kompetensi psikomotor siswa menunjukkan bahwa kompetensi psikomotor siswa juga meningkat pada setiap pertemuan. Pada pertemuan pertama, nilai rata-rata persentase kompetensi psikomotor siswa adalah 60,9\%. Nilai ini kemudian meningkat menjadi $79,1 \%$ pada pertemuan kedua, dan $90,3 \%$ pada pertemuan ketiga. Nilai yang sudah meningkat ini kemudian meningkat lagi pada pertemuan keempat menjadi 96,2\% pada pertemuan keempat dan 97,3\% pada pertemuan kelima.

Peningkatan

kompetensi psikomotor siswa yang terjadi karena perangkat pembelajaran fisika berbasis pendidikan karakter dengan model problem based instruction mendorong siswa untuk menggunakan pemikirannya secara optimal dalam menemukan pemecahan suatu masalah yang telah dirumuskan dengan memberikan kesempatan kepada siswa untuk melatih kompetensi psikomotornya pada setiap pertemuan melalui serangkaian eksperimen yang telah disiapkan. Hal ini dikarenakan salah satu langkah dari model problem based instruction mengharuskan siswa untuk melaksanakan eksperimen dalam menemukan pemecahan masalah yang telah dirumuskan. Selain itu arahan serta motivasi dari guru juga memegang peran yang penting dalam peningkatan kompetensi psikomotor siswa ini.

Aktivitas belajar siswa mengalami peningkatan pada setiap pertemuan. Nilai rata-rata persentase aktivitas siswa untuk lima kali pertemuan secara berturut-turut adalah $54,1 \%, 68,3 \%, 81,7 \%, 88,8 \%$, dan $94,8 \%$. Peningkatan aktivitas belajar siswa terjadi karena model problem based instruction menuntun siswa untuk menggunakan pemikirannya sejak awal pembelajaran dimulai. Akibatnya, karena pikiran siswa sudah difokuskan pada pembelajaran sejak awal, aktivitas belajar siswa menjadi lebih mudah untuk diarahkan. Dengan kata lain, berawal dari mengoptimalkan aktivitas berpikir siswa, aktivitas belajar siswa yang lain menjadi ikut terangsang untuk dilakukan siswa. Hal ini tidak terjadi pada pertemuan pertama, karena pada pertemuan pertama siswa masih terlihat menyesuaikan diri dengan model pembelajaran problem based instruction yang diterapkan. Selain itu, model problem based instruction ini juga menuntun siswa untuk melakukan berbagai aktivitas, mulai dari merumuskan masalah, memahami isi modul, melaksanakan eksperimen, mempresentasikan hasil eksperimen, sampai pada aktivitas menganalisis dan mengevaluasi hasil pemecahan masalah. Dengan demikian, aktivitas siswa menjadi bervariasi tidak monoton hanya duduk mendengarkan penjelasan guru saja. Hal seperti ini mau tidak mau menuntut siswa untuk mengikutsertakan diri dalam setiap kegiatan pembelajaran.

Model problem based instruction juga dapat meningkatakan aktivitas belajar siswa karena setiap langkah model ini saling berkaitan. Bisa dikatakan bahwa setiap langkah model problem based instruction merangsang siswa untuk aktif dalam langkah berikutnya, misalnya dalam diskusi. Aktivitas siswa dalam berdiksusi tidak akan mengingkat jika siswa tidak memiliki modal atau bahan untuk disampaikan, dan modal ini telah diperoleh siswa dalam aktivitas sebelumnya yaitu melalui aktivitas pemahaman isi modul dan aktivitas eksperimen. Hasil penelitian ini sejalan d 


\section{SIMPULAN DAN SARAN}

Berdasarkan hasil pengembangan dan uji coba yang telah dilakukan, dapat disimpulkan bahwa hasil validasi dari para validator menunjukkan bahwa perangkat pembelajaran fisika berbasis pendidikan karakter dengan model problem based instruction, sangat valid, sangat praktis, dan sangat efektif. Efektifitas perangkat ditunjukkan pula dengan adanya peningkatan aktivitas dan hasil belajar siswa

Berdasarkan penelitian yang telah dilakukan, maka disarankan hal-hal sebagai berikut.

1. Melakukan uji coba dibeberapa sekolah untuk mendapatkan hasil yang lebih maksimal

2. Mengembangkan perangkat pembelajaran fisika berbasis pendidikan karakter dengan model problem based instruction pada materi fisika lainnya

3. Melaksanakan beberapa kali pertemuan lagi agar perkembangan perilaku berkarakter siswa menjadi lebih baik dan konsisten

4. Melanjutkan pengembangan sampai pada tahap penyebaran (dissemination)

DAFTAR PUSTAKA

Akhlis, I., \& Dewi, N. R. (2014). Pengembangan Perangkat Pembelajaran Sciense Berorientasi Cultural Deviance Solution Berbasis Inkuiri Menggunakan ICT untuk Mengambangkan Karakter Peserta Didik. Jurnal Pendidikan IPA Indonesia, 86-94.

Diani, R. (2015). Upaya Meningkatkan Aktivitas dan Hasil Belajar Fisika SIswa dengan Menggunakan Strategi Pembelajaran Aktif Tipe Inquiring Minds Want to Know di SMP Negeri 17 Kota Jambi.
Jurnal Ilmiah Pendidikan Fisika Al-Biruni, 133-143.

Diani, Rahma. Pengembangan Perangkat Pembelajaran Fisika Berbasis Pendidikan Karakter dengan Model Problem Based Instruction dan indikator dampaknya terhadap kompetensi siswa, $\mathrm{M}$. Pd. Tesis. Pendidikan Fisika Program Pascasarjana Universitas Negeri Padang, 2013.

Gunawan, Heri. 2012. Pendidikan Karakter: Konsep dan Implementasi. Bandung: Alfabeta.

Izzati, N., Hindarto, N., \& Pamelasari, S. D. (2013). Pengembangan Modul Tematik dan Inovativ Berkarakter pada Tema Pencemaran Lingkungan untuk Siswa Kelas VII SMP. Jurnal Pendidikan IPA Indonesia, 183-188.

Riyanto, Yatim. 2010. Paradigma Baru Pembelajaran: Sebagai Referensi bagi Guru/Pendidik dalam Implementasi Pembelajaran yang Efektif dan Berkualitas. Jakarta: Kencana.

Rusman. 2011. Model-Model Pembelajaran Mengembangkan Profesionalisme Guru. Jakarta: PT. Rajagrafindo Persada

Taufiq, M., Dewi, N. R., \& Widiyatmoko, A. (2014). Pengembangan Media Pembelajaran IPA Terpadu Berkarakter Peduli Lingkungan Tema "Konservasi" Berpendekatan ScienceEdutainment. Jurnal Pendidikan IPA Indonesia, 140-145.

Widiyatmoko, A. (2013). Pengambangan Perangkat Pembelajaran IPA Terpadu Berkarakter Menggunakan Pendekatan Humanistik Berbantu Alat Peraga Murah. Jurnal Pendidikan IPA Indonesia, 76-82. 